\title{
An Appraisal of Economic Dimension in Nigeria's Multilateral Diplomacy
}

\section{Oladimeji Talibu}

School of International Studies, Universiti Utara Malaysia, MALAYSIA

*Corresponding Contact:

Email: otalibu@yahoo.com

\begin{abstract}
Nigeria's multilateral economic policy has come under scrutiny and criticism in recent years from policy quarters and informed publics. This becomes necessary because of the perceived policy discrepancy between policy intention and outcome. Most Nigerians, especially from the academia and policy quarters, continue to reassess Nigeria's place in international institutions vis-à-vis its national goals and interests. This article is therefore an extension of such exercise, to assess and explore a section of Nigeria's involvement in multilateral institutions since 1960, the year of independence. It explores and assesses the economic aspect of Nigeria's multilateral policy and seeks to appraise what Nigeria has benefitted from its decades of involvement in multilateral organizations. In achieving this, the article uses latent content analysis to mine data from existing documents, journal articles, newspapers, and policy papers to dissect the process of multilateralism in Nigeria's foreign policy. In addition, the article takes into consideration the use of hermeneutics approach, which is premised on the interpretation of all available evidence, to arrive at objectivity.
\end{abstract}

Key Words: Economy, Multilateral Diplomacy, Foreign Policy, Nigeria

\section{INTRODUCTION}

The government of each state in the global economy devises means and strategy by which its economic interest will be protected and strengthened against other state actors within the global economic space. The economic capacity of a state is an important instrument of foreign policy, and it determines the complexity and orientation of such policy (AdeyemiSuenu \& Inokoba, 2010:1). Some countries, especially the developed ones, promote multilateral diplomacy to ensure stable political and economic climate in the global space, which will ensure the smooth running and flow of goods and services across borders (Gill \& Law, 1989:478). The promotion of and stability of global economic system has and still is the responsibility of hegemon in the international system. In the $18^{\text {th }}$ century, Britain dominated the global economy and maintained the system until it displaced by the U.S. after the First World War. The U.S. also fashioned out its own hegemonic device, which dominates the global economic terrain until now. In the contemporary global system, such hegemonic role is being displayed and sponsored at regional and sub-regional level of multilateralism. 
The Nigerian economy at the point of independence gave Nigerian leaders hope and certainty that the country will soon become an industrial hearth of the continent (Herskovits, 2001:314). It needs to be stressed here that there are three important ways by which economy affects Nigerian multilateral policy. First, the large and robust economy, at least by African standard, gives Nigerian leaders the idea of promoting integration in Africa. Second, the relative advanced economy, in addition to oil, gives Nigeria the opportunity to finance some of its ambitious plans, most especially in the Organization of African Unity (OAU) and Economic Community of West African States (ECOWAS) (Herskovits, 1975:316; Shaw \& Fasehun, 1980:554). Third, the need to solve some problems posed by commodity trade, debt burden, poverty, underdevelopment and African marginalization is also an important area by which economy impacts on Nigerian multilateral policy (Alli, 2012:68). Professor Joy Ogwu, the permanent representative of Nigeria to the UN, stressed that,

Economic concerns underpin Nigeria's role in the ECOWAS....Effective regional cooperation and integration in Africa is critical to the solution of the country's numerous problems....It is impossible to solve the problems posed by poverty and debt burden on an individual country basis... and for this to be effective... Nigeria is expected to play this role in view of her status as the largest market in the sub-region with vast natural and human resources.... The role of hegemon is also expected of Nigeria at the continental level...where the country was a protagonist for the recently established $A U(O g w u, 2005: 10)$.

Since independence in 1960, many countries have constantly lived with the convictions that Nigeria is in the best position to protect the economic interest of Africa. Thus, many countries and individuals at Nigeria independence in 1960 were of the belief that Nigeria would compete favorably with countries like Brazil, Mexico and Argentina (Shaw, 1983:6-7). The economic prosperity was promising and the Nigerian leaders were convinced of the need to dominate African market. With the largest market in Africa signified by overwhelming population and resources, Nigeria started proposing African integration as a platform to launch itself as Africa's economic powerhouse (Brown, 1989:258). At independence, the Nigeria's future economy was promising given the leaders the idea that Nigeria needed to promote "Pax Nigeriana" and to be a leader in Africa as its "manifest destiny" (Adebajo, 2003:64).

\section{NIGERIA's ECONOMY AS A FACTOR OF MULTILATERALISM}

The huge population coupled with oil and other agricultural resources like cocoa, groundnut, palm oil, rubber and cotton, gave an impressive outlook on the economy. In 1970 alone, Nigeria supplied 3.5\% (2,376,000 tons) of the crude oil export to the US, placing it at the comfortable position to dominate African political terrain (Bach, 1983:43). In 1979, Nigeria rose to the seventh position in the world in the production of crude oil and occupied the first position in Africa (Wright, 1983:98). In 1963, Nigeria's population represented 25\% of African's and such demographical preponderance made it attractive to the investors coming to Africa (Wright, 1983:100). The agricultural produce was amounted to $\$ 6.3$ billion in 1970 and was ranked $9^{\text {th }}$ in the world alongside Turkey (Kushnir, 2013). Also in 1970, the Nigerian agricultural production represented $27.1 \%$ and $65 \%$ of Africa and West Africa respectively (Kushnir, 2013). This huge economy thus prompted Nigerian leaders to promote multilateralism under which the Nigerian economy can be galvanized into developed ones. In this sense, the need to dominate African economy and market was behind the Prime Minister's sponsoring of West Africa Economic Community in 1964 (Shaw, 1983:1). It did not come to fruition and continued subsequently by other Nigerian leaders. 
It should be noted that by the time Nigeria gained its independence, it saw the International monetary Fund (IMF), General Agreement on Tariff and Trade (GATT), and the World Bank (WB) as colonial economic instrument to further perpetuate their hegemonic role in the global economy (Wright, 1998:136). This idea emanated from the situation Nigeria found itself and some African countries at independence. Most African countries were all enmeshed in economic underdevelopment and abject poverty and Nigerian leaders, especially those with communist orientation, accused the West of conspiracy to put Africa at the bottom of ladder in the global economy (Rodney, 1973). It was based on this that Nigerian joined other developing countries from Asia and Latin America to form G-77, an economic caucus within the UN, which advocated for New International Economic Order (NIEO) in 1964 in response to G7 (Akinrinade, 1998:173). In the process, Nigeria was trying to devise a continental economic multilateral institution that will cater for its interest and that of Africans. Between 1960s and 1970s Nigeria's economy had already been growing steadily and by 1970 , the Nigeria's annual growth rate was $44.8 \%$ which amounted to $\$ 11.4$ billion (Kushnir, 2013). In the same year, Nigeria's GDP was $\$ 25.4$ billion representing 23.1\% and $72.1 \%$ of Africa and West Africa respectively and was ranked $20^{\text {th }}$ globally (Kushnir, 2013). By 1970s it was in the economic caucus of Newly Industrialized Countries (NICs) contesting economic buoyancy and competition with countries like Brazil, Argentina, South Korea and Mexico which were then located in the semi-periphery (Shaw, 1983:7). It needs to be stressed that oil had become an important aspect of Nigerian economy in 1970s after successful prospecting and exploration in the 1960s.

The history of oil exploration in colonial Nigeria started between 1903 and1958 when the first shipment of Nigerian crude oil arrived in Rotterdam (Mayall, 1976:289). The oil economy was not as significant as commodity economy after independence and most of the government revenue came from the exportation of cocoa, palm oil, rubber, cotton, groundnut and coffee (Oladimeji and Kirmanj, 2015:687). Oil export began to be significant in Nigerian economy shortly after the civil war (Herskovits, 1975:313). The radicalization of foreign policy in the 1970s coincided with the height of Nigerian influence in foreign affairs, thanks in no small part to the oil boom and the rise of oil price that occurred in the years after the conclusion of the civil war. The wealth that came from oil revenues enabled the country to become an important source of aid throughout Africa (Shaw, 1984:394). At the same time, Nigeria was able to use its oil as a bargaining chip with the western powers that purchased it and used it to meet their energy needs.

In 1960, Nigeria produced 6,367 barrel of crude oil per day while it astronomically rose to 395,905 barrel in 1970. Angola, a rival oil producer in sub-Saharan Africa, produced 1,100 and 83,900 barrel of crude oil in 1960 and 1970 respectively (Organization of Petroleum Exporting Countries (OPEC), 2014). The enormous resources that Nigerian leaders inherited after independence created suspicion in the global political economy that Nigeria would soon become the "Second Brazil" (Shaw, 1983). London Financial Times buttressed this claim further,

In a world economy that is basically reliant on oil, Nigeria's economic and strategic importance is enormous.... Increasingly, Nigeria's wealth and position has immensely enhanced her political and strategic importance in Africa and world politics. A strong member of OPEC, a pioneer and stabilizing force in the OAU, a member of the non-aligned nations, a founder of ECOWAS, Nigeria is slowly but assuredly emerging as major factor in the global power calculus (Financial Times, March 17, 1981). 
As a member of OPEC and OAU, Nigeria has used its economic resources to pursue its strategic interest. According to Andrew Young, a leading activist in improving US-Nigerian relations under President Jimmy Carter of the US and General Olusegun Obasanjo of Nigeria,

Nigeria will endeavor to foster its interest in economic development and stable trade relationship with the west while simultaneously continuing to use its leverage with western nations and corporations in the interest of its political goals on the African continent especially with regard to South Africa (cited in Shaw, 1983:5).

This reveals the extent of Nigeria's employment of economy as an instrument of diplomacy in dealing with the outside world. The most important of Nigeria economy is oil which has created enormous wealth and influence for Nigeria in the international system. This oil economy provides Nigeria with much-needed revenue to pursue ambitious regional integration in Africa. In 1966, for example, oil production contributed 5.8\% of Nigeria's GDP but rose to $14 \%$ in 1973 (Tyoden, 1983:153).

By 1974, Nigeria had become the sixth largest oil producer in the world and was the second largest supplier to the U.S. after Saudi Arabia (Akinterinwa, 2005:88). As long as oil prices remained high, as it did for most part of President Gowon period (1970-1975), Nigeria was a force to be reckoned with in international affairs. The oil weapon, therefore, became an important instrument in Nigerian foreign policy; it was used both to reward allies and to punish opponents by the Gowon government (Oladimeji and Ahmad Zaki, 2015:406). The statistics below is a testimony to the astronomical increase in Nigerian export revenue from oil during President Gowon administration. During this period of oil boom, it is on record that Gowon lamented that "the problem of Nigeria is not money but how to spend it" (Morning Post, October 23, 1968).

Table 1: Petroleum of Production and Export

Petroleum of Production and Export

\begin{tabular}{cccccc}
\hline Year & $\begin{array}{c}\text { Crude oil } \\
\text { production per } \\
\text { thousand barrels }\end{array}$ & $\begin{array}{c}\text { Crude oil } \\
\text { production per } \\
\text { thousand tones }\end{array}$ & $\begin{array}{c}\text { Crude oil exports } \\
\text { per thousand } \\
\text { barrels }\end{array}$ & $\begin{array}{c}\text { Crude oil exports } \\
\text { per thousand } \\
\text { tones }\end{array}$ & $\begin{array}{c}\text { Natural gas } \\
\text { production million } \\
\text { cubic feet }\end{array}$ \\
\hline 1958 & 1,876 & 257 & 1,695 & 230 & 1,609 \\
1959 & 4,096 & 561 & 4,065 & 552 & 4,939 \\
1960 & 6,367 & 872 & 6,244 & 849 & 5,095 \\
1961 & 16,802 & 2,283 & 16,506 & 2,243 & 10,943 \\
1962 & 24,624 & 3,346 & 24,680 & 3,421 & 17,179 \\
1963 & 27,913 & 3,793 & 27,701 & 3,754 & 22,106 \\
1964 & 43,997 & 5,978 & 43,432 & 5,878 & 36,333 \\
1965 & 99,853 & 13,567 & 96,985 & 13,234 & 79,438 \\
1966 & 152,428 & 20,710 & 140,118 & 19,333 & 103,820 \\
1967 & 116,525 & 15,832 & 109,057 & 15,011 & 93,950 \\
1968 & 51,907 & 7,053 & 52,847 & 7,180 & 51,628 \\
1969 & 197,204 & 26,794 & 197,246 & 26,984 & 145,714 \\
1970 & 395,905 & 53,791 & 383,455 & 52,100 & 285,512 \\
1971 & 558,828 & 75,928 & 542,545 & 73,984 & 458,973 \\
1972 & 665,286 & 90,392 & 650,980 & 88,431 & 604,642 \\
1973 & 750,609 & 101,985 & 723,314 & 99,688 & 772,777 \\
1974 & 823,349 & 112,788 & 795,710 & 109,662 & 959,524 \\
\hline
\end{tabular}

Source: Nigeria Ministry of Mines and Power, Petroleum Division.

With such huge amount of revenue derived from oil economy, Nigerian government started to pursue regional integration ambition in Africa. The astronomical increase in the production of oil 
in the 1970s could be attributed to the energy crisis of the 1970s which was a result of Arab oil embargoes on the U.S. The embargoes led to the renewed interest in the Nigerian oil by the U.S. who perceived the Middle East source of energy as unstable and unreliable. This spurred increased in the volume of production and price as opposed to pre-1970s. The ECOWAS campaign had started since 1964 but with heavy financial clout in the 1970s Nigeria was able to sponsor some projects in West Africa to motivate West African countries to cooperate with the formation of regional organization. One of the projects was the supply of electricity to Niger Republic from Nigeria's Kanji dam which amounted to 9.6 million naira (\$6.32 million) in 1972 and this convince some of the west African countries of the readiness of Nigeria to shoulder in its totality the responsibility of the regional organization (Oladimeji \& Ahmad Zaki, 2015:403).

With the outbreak of the Arab-Israeli war in 1973, Nigeria broke off diplomatic relations with Israel and participated in the OPEC oil embargo against the U.S., illustrating its solidarity with its oil producing Arab allies while simultaneously using the oil weapon against a formidable western foe (Wright, 1983:108). In addition to this, OPEC as a multilateral cartel served Nigeria multilateral policy well in dealing with the West on the issues of Palestine and Southern African countries (Oladimeji \& Kirmanj, 2015:685). Nigerian government gave substantial amount in aid and loan to some poor OAU member countries who could not cope with the high price of oil in the global market. For example, in 1972 the Gowon government donated $\$ 158,000$ to Kenya, $\$ 75,000$ to Guinea and $\$ 150,000$ to the Sudan (Nwoke, 2005:121). Such generosity was paid for with oil revenues, which by 1974 accounted for 90\% of Nigeria's export earnings and over $80 \%$ of its total revenue (Herskovits, 1975:315). In 1975, Nigeria started to use its oil as economic and political tools and began selling petroleum directly to African countries at concessionary rates. African countries were allowed to purchase Nigerian crude oil at three-quarters of the market price (Guardian, October 30, 1990). This was premised on conditions that the purchasing country had its own refineries and that the country agreed not to resell the oil to third parties. By this, Nigeria hoped to stimulate relations with African countries and help struggling African economies get on their feet. With the oil revenue and attendant assistance to OAU members, the West African countries agreed with Nigeria in 1975 and ECOWAS was formed with largely Nigerian oil revenue (Nwoke, 2005:124).

Such oil revenue also provided Nigeria with huge financial resources to meet its obligations in UN, OPEC and OAU. According to the latest estimate, Nigeria is the largest oil producer in Africa and occupies $13^{\text {th }}$ position in the global production. Nigeria's oil production constitutes 2.62\% of global oil production and export in 2013 (OPEC, 2014). In addition to this, Nigeria is by far the largest oil producer in ECOWAS and in terms of global agricultural produce, Nigeria is also the third largest producer of palm oil in the world after Indonesia and Malaysia (United States Department of Agriculture, 2014). Its cocoa production also constitutes $7.7 \%$ of global production in 2012 making Nigeria the $4^{\text {th }}$ largest producer in the world (World Cocoa Foundation, 2014). Nigeria's record in strategic resources is notable and it is by far the richest country in Africa in all essential products (Bach, 2007). In 2014, Nigeria surpassed South Africa as the largest African economy.

Thus, the ECOWAS and its military offspring, ECOMOG, rest solely on Nigerian financial capability, as most ECOWAS members are very poor to meet their financial commitments (Daily Champion, July 8, 2003). In 2002 only, Nigeria paid \$60million which represented 60\% of the whole amount for ECOWAS currency stabilization while Ghana, Guinea and Gambia paid $17 \%, 5 \%$ and $0.07 \%$ respectively of the $\$ 100$ million allotted (Comet, May 21, 2002). In essence, without the huge financial contribution of Nigeria, ECOWAS cannot survive the ravages of time. In sponsoring ECOWAS and AU, Nigeria is of the view that the free 
movement of people and common currency could open the African market to Nigerian exports as it competes with France, the U.S., Britain and recently Japan and China (Nigerian Tribune, October 17, 2013). To achieve this laudable goal, Nigeria sponsored the construction of West African Gas Pipeline (WAGP) covering $997 \mathrm{~km}$ miles long off-shore which is intended to supply some ECOWAS member countries with Nigerian gas (Nwoke, 2005:127). Monetary union had also been sponsored which was formerly scheduled to materialize in 2005 but due to some political and economic circumstances in the region, Nigeria could not attain this. The formation and implementation on the monetary union is still in progress. The buoyant economy therefore could be adjudged as an important factor in Nigeria's multilateral policy.

\section{ACHIEVEMENTS}

One of the most important factors that dictate Nigeria's multilateral policy is economy which has been dealt with in the previous section. In adopting multilateral policy as a mechanism of promoting its economic interest in the global stage, Nigeria has recorded some achievements especially in connection with ECOWAS. Before the formation of ECOWAS in 1975, Nigeria has engaged itself in some steps that would advance its domestic economic interest in the global arena. In the first instance, Nigeria's economy was basically backward by modern global standard and therefore could not compete favorably with industrialized countries. In this way, Nigeria opted for regional economic integration in Africa. The first step taken in this direction was the need to advance the collective interest of African economy which began with the leading of African negotiation with European Economic Community (EEC) in 1973 (Aluko, 1983:84). Osuntokun (2005:41) states that "whenever Nigeria found a forum, whether in the non-aligned conferences, the OAU, ECOWAS, the Commonwealth and the UN, economic concern and preoccupation dominated our declarations and speeches".

It is of interest to elaborate more on the issue of Nigeria and the EEC because it defined the final faith of ECOWAS formation in 1975. Earlier in 1971, the EEC countries were trying to reduce tariff on goods and services that came from Africa as most of their exports were primary products (Ogunsawo, 2005:202). The EEC thus wanted to enter into negotiation with African countries of which Nigeria was indispensable. The then Nigerian Commissioner for Trade, Wenike Briggs, was of the view that joining the negotiation with other African countries would be of benefit to Nigeria in order to motivate the west African countries in the formation of ECOWAS (Aluko, 1983:85). Some Nigerians who worked in the Ministry of Foreign Affairs and Economic Development were of the conviction that the economic negotiation with the EEC was not beneficial to Nigerian economy in any way. One of the arguments against the negotiation was that Nigeria did not rely on agricultural product as $80 \%$ of its export came from oil and its agricultural export to European market was less than $10 \%$ of which Nigeria could not benefit from Système de Stabilisation des Recettes d' Exportation (STABEX) arrangement (Wright, 1998:139). The STABEX arrangement was based on the idea that those African countries whose export to European market constitute over $10 \%$ of agricultural products will benefit from tariff reduction. According to Ogunsawo (2005:203) "as long as Nigeria did not fall under this categorization it made no sense to join the economic negotiation with EEC". At last in 1975, through appraisal and assessment of the regional economic cooperation, Nigeria decided to lead the OAU members to negotiate with the EEC. Olajide Aluko argues further,

in terms of direct monetary benefits, Nigeria did not expect much. On the contrary Nigeria government saw its decision to participate in the negotiation as a way to promote African unity and reduce economic... balkanization (Aluko, 1983). 
Another senior official in the negotiations, Dr. Olu Sanu, observed that "history might also record that Nigeria's act of solidarity with African states was a major contribution towards the goal of African unity and inter-African economic cooperation" (Sanu, 1980). It needs to be stated here that the negotiation was led by Nigeria purely to secure favorable trade relation between Africa and Europe which has gone down in the history as one of the earliest successes of Nigeria's multilateral diplomacy. The negotiation has proved to be useful in Nigeria's economy as Nigeria has grown to be the largest EU trading partner in the West African sub-region (Akinterinwa, 2005:94). The table below illustrates the pattern of trade between ECOWAS and European Union (EU).

Table 2: ECOWAS-EU Trade Investment Statistics

\begin{tabular}{|c|c|c|c|c|c|c|c|c|c|}
\hline & 2000 & 2005 & 2009 & 2010 & $\begin{array}{l}\text { Growth } \\
\text { rate } \\
2009 / 2010\end{array}$ & $\begin{array}{c}\text { Annual } \\
\text { average } \\
\text { growth } \\
\text { rate } \\
2009 / 2010\end{array}$ & $\begin{array}{c}\text { Shares in } \\
\text { total Extra } \\
\text { EU-27 } \\
\text { imports } \\
(2010)\end{array}$ & $\begin{array}{c}\text { Shares in } \\
\text { Eu-27 } \\
\text { imports } \\
\text { from Africa } \\
\text { (2010) }\end{array}$ & $\begin{array}{c}\text { Shares in } \\
\text { Eu-27 Import } \\
\text { From } \\
\text { ECOWAS } \\
(2010)\end{array}$ \\
\hline ECOWAS & 11561 & 13738 & 16496 & 21169 & $26.3 \%$ & $6.2 \%$ & $1.41 \%$ & $15.83 \%$ & $100.00 \%$ \\
\hline Benin & 81 & 33 & 31 & 31 & $0.5 \%$ & $-9.1 \%$ & $0 . .00 \%$ & $0.02 \%$ & $0.15 \%$ \\
\hline Burkina Faso & 70 & 30 & 82 & 99 & $20.5 \%$ & $3.6 \%$ & $0.01 \%$ & $0.07 \%$ & $0.47 \%$ \\
\hline Cape Verde & 13 & 19 & 27 & 36 & $35.0 \%$ & $11.0 \%$ & $0.0 \%$ & $0.03 \%$ & $0.17 \%$ \\
\hline Gambia & 32 & 6 & 11 & 18 & $61.4 \%$ & $-5.6 \%$ & $0.0 \%$ & $0.01 \%$ & $0.09 \%$ \\
\hline Ghana & 1173 & 978 & 1097 & 1458 & $32.9 \%$ & $2.2 \%$ & $0.10 \%$ & $1.09 \%$ & $6.89 \%$ \\
\hline Guinea & 523 & 445 & 384 & 472 & $22.9 \%$ : & $-1.0 \%$ & $0.03 \%$ & $0.35 \%$ : & $2.23 \%$ \\
\hline GuineaBissau & 5 & 3 & 2 & 6 & $143.5 \%$ & $1.2 \%$ & $0.00 \%$ & $0.00 \%$ & $0.03 \%$ \\
\hline Ivory Coast & 2059 & 1978 & 3054 & 3215 & $5.3 \%$ & $4.6 \%$ & $0.21 \%$ & $2.41 \%$ & $15.19 \%$ \\
\hline Liberia & 435 & 926 & 533 & 341 & $-35.9 \%$ & $-2.4 \%$ & $0.02 \%$ & $0.26 \%$ & $1.61 \%$ \\
\hline Mali & 76 & 42 & 20 & 27 & $34.5 \%$ & $-9.8 \%$ & $0.00 \%$ & $0.02 \%$ & $0.13 \%$ \\
\hline Niger & 95 & 130 & 219 & 196 & $-10.6 \%$ & $7.5 \%$ & $0.01 \%$ & $0.15 \%$ & $0.93 \%$ \\
\hline Nigeria & 6491 & 8389 & 10417 & 14592 & $40.1 \%$ & $8.6 \%$ & $0.97 \%$ & $10.91 \%$ & $68.93 \%$ \\
\hline Senegal & 410 & 521 & 261 & 297 & $13.5 \%$ & $-3.2 \%$ & $0.02 \%$ & $0.22 \%$ & $1.40 \%$ \\
\hline Sierra Leone & 105 & 121 & 100 & 159 & $59.5 \%$ & $4.3 \%$ & $0.01 \%$ & $0.12 \%$ & $0.75 \%$ \\
\hline Togo & 65 & 116 & 258 & 221 & $-14.4 \%$ & $12.9 \%$ & $0.01 \%$ & $0.17 \%$ & $1.04 \%$ \\
\hline
\end{tabular}

Source: ECOWAS-EU Trade and Investment Statistics, 2000-2010

The table above reveals that the bulk of EU imports from ECOWAS member states are from Nigeria which would have otherwise difficult if Nigeria did not sponsor the negotiation of Africa Caribbean and Pacifics (ACP)-EEC in 1973. Although it may be right to assert that since oil forms $80 \%$ of merchandise export to EU from Nigeria, it is expected that Nigeria forms the single largest trading partner of EU in West Africa.

It is of interest to note that Nigeria as economic powerhouse of Africa promotes regional economic integration in order to enhance its economic productivity in Africa and most especially within the West African sub region (The Guardian, October 30, 2010). After successful formation of ECOWAS in 1975, the trade relationship between Nigerian and its West African counterparts have been on the upsurge. Nigerian successfully launched Free Trade Agreement, ECOWAS Common Currency, Custom Union, and promotion of the free movement of the people across West African countries (The Nation, December 30, 2010). In addition, the successful adoption of Lagos Plan of Action after the economic summit, which propagated and promoted common 
market among African countries in 1980 led to the adoption of collective self-reliance and regional integration. This in turn boosted Nigeria's confidence in West Africans markets (Nwoke, 2005:123). Thus, because of nature of Nigerian economy, which is based on the oil export, Nigeria records trade surplus with ECOWAS, EU, and AU member states. Below is the recent summary of Nigeria's trade relations with the aforementioned blocs.

Table 3: Selected trade partners for Nigeria (2009-2012) (data given in thousands of USD)

\begin{tabular}{ccccc}
\hline & $\mathbf{2 0 0 9}$ & $\mathbf{2 0 1 0}$ & $\mathbf{2 0 1 1}$ & $\mathbf{2 0 1 2}$ \\
\hline Import from AU & 2416245 & 2911749 & 2920450 & 1566375 \\
Export to AU & 8510888 & 10494748 & 13092447 & 21022001 \\
Trade Balance & 1017028 & 5327757 & 10215305 & 14164371 \\
Import from EU & 7799669 & 9658924 & 15642145 & 8356760 \\
Export to EU & 11203780 & 19406833 & 35759834 & 50998444 \\
Trade balance & 3404111 & 9747909 & 20117689 & 42641684 \\
Import from ECOWAS & 71631 & 182836 & 753499 & 151833 \\
Export to ECOWAS & 2151288 & 2044825 & 3579659 & 5545051 \\
Trade balance & 2079657 & 1861989 & 2826160 & 5393218 \\
\hline
\end{tabular}

Source: International Trade Centre (2014)

It needs to be reiterated that the favorable balance of trade surplus between Nigeria, ECOWAS and AU members signifies the success Nigeria has attained in its multilateral policy in relation to economy. Although one may wonder why ECOWAS members' export to Nigeria is comatose in relation to imports, it should be stressed that majority of ECOWAS member states are mono-product economy and the political economy of the region is not complementary but competitive in nature (Nwoke, 2005:124). Apart from surplus trade relation with AU and ECOWAS members, Nigeria also enjoys the investment climate of ECOWAS and AU members based on the signing of protocol relating to trade relation among the ECOWAS and AU members (The Nation, June 19, 2013). Such protocol enhances Nigeria to boost its investment in other parts of Africa. In fact, Nigerian Ambassador to Ghana, Ademola Oluseyi, affirms that any trade dispute that may arise between Nigerians in Ghana can be settled by ECOWAS Protocol amicably (Business News, September 23, 2014). By ECOWAS and AU protocols, Nigerian investment in African countries has grown steadily over years. In his word, Mr. George Aboagye, Chief Executive Officer of Ghana Investment Promotion lamented that there were 17 Nigerian firms operating in Ghana at present and their total capital amounted to $\$ 1.5$ billion between 1994 and 2011 (The Nation, August 14, 2014). In a similar reaction, the Chief Executive Officer also stressed that, "the regional integration of which Nigeria is a prime factor has yielded considerably for Nigerians in some African countries as most Nigerian banks and other private investors are eyeing countries like Ghana, Togo, Zambia and Rwanda".

Nigeria is among the five top investors in Rwanda and investment in cement, building materials, concrete products, insurance, banking, petroleum and real estate are the areas where Nigeria dominate market in other parts of Africa (Tetenyi, 2014). Ademola Oluseyi, the Nigerian ambassador to Ghana, also stated that seven Nigerian banks are now in operation in Ghana. They are United Bank for Africa, First Atlantic Bank, Zenith Bank, Access Bank, Equity Assurance, Regency Alliance, and NEM Insurance. He also stressed that the Nigerian investment totaled \$2 billion in 2014 in Ghana alone (Sun News (Ghana), September 16, 2014). Other Nigerian companies operating in African countries are Dangote Groups, African Petroleum, Oando and SO Energy (Business News, September 23, 2014). Unipetrol also operates in Sierra Leone, Togo, and Ghana where it dominates the $70 \%$ of Sierra Leonean terminal tankage and secured five retails outlets in Togo (The Guardian, September 18, 2002). In essence, Nigeria's multilateral policy has paved the way for reliable investment climate in some African countries. 


\section{CONCLUSION}

The article has attempted to dissect Nigeria's multilateral diplomacy through economic lens. Such exercise has revealed important information about Nigeria's multilateral diplomacy. Nigeria's relative advance economy in Africa propels it to shoulder most of the continental responsibilities from 1960. Such responsibilities have allowed Nigeria to sponsor and direct the affairs of Africa through multilateral institutions like ECOWAS, OAU (now AU) and UN. Because of Nigeria's relative advance in economy, it enables the sponsorship of many projects within African continent. In addition, Nigeria benefits from the generous UN loan to finance some of its domestic infrastructures. Within the West African sub region, Nigeria has employed ECOWAS to advance its economic interest in West Africa which has ultimately enabled it to capture, at least in modest form, the regional market. Thus, multilateral diplomacy yielded many benefits to Nigeria as a state. However, Nigeria's comatose industrial production and infrastructural deficiency make full utilization of its economic potential impossible among its peers in the multilateral institutions. This is most especially true of South Africa, Algeria, Egypt, and some other countries outside Africa. Nigeria's miniature industrial facilities cannot compete with some of these countries, which make some African countries to resent implicitly Nigeria's leadership posture in Africa. Thus, for Nigeria to make full utilization of multilateral diplomacy, its economic sector, premised on diversification and infrastructural development, must be reinvigorated.

\section{REFERENCES}

Adebajo, A. (2003) In Search of Warlords: Hegemonic Peacekeeping in Liberia and Somalia International Peacekeeping, 10(4), 62-81.

Adeyemi-Suenu, W. \& Inokoba, P. K. (2010). Commitment Capability and Nigeria's Strategic Interest in West Africa: Lessons for Statesmen. Journal of social science, 22(3), 179-184.

Akinrinade, S. (1998). Africa and the United Nations. In A. Sola \& S. Amadu (Eds), Africa in the postcold war international system (pp. 173-194). Great Britain: Pinter Publishers.

Akinterinwa, B. (2005). Nigeria and France in the new century: policy prognosis, problems and prospects. ECOWAS in O. Joy (Ed.) new horizons for Nigeria in world affairs (pp.81-110). Lagos: NIIA Publications

Alli, W. O. (2012). The role of Nigeria in regional security policy. Nigeria, Abuja: Friedrich Ebert-Stiftung.

Aluko, O. (1983). Bureaucratic politics and foreign policy decision-making in Nigeria. In S.M Timothy \& A. Olajide (Eds), Nigerian foreign policy: alternative projections (pp.77-92). Hong Kong: Macmillan Press Ltd.

Bach, D. (1983) Nigerian-American relations: converging interests and power relations. In S.M. Timothy \& A. Olajide (Eds), Nigerian foreign policy: alternative projections (pp.23-55). Hong Kong: Macmillan Press Ltd.

Bach, D. (2007). Nigeria's' manifest destiny in West Africa: dominance without power. Africa Spectrum $42(2), 301-321$.

Business Day (2015, May 29) retrieved http:/ /www.bdlive.co.za/africa/africannews/2015/05/29/nigerias-akinwumi-adesina-votednew-afdb-chief.

ECOWAS-EU trade and investment statistics, 2000-2010. Retrieved from http:/ / ec.europa.eu/eurostat/statistics-explained/index.php/ECOWAS-EU__trade_and_investment_statistics on 25/3/2015

Gill, S. \& Law, D. (1989).Global hegemony and the structural power of capital. International Studies Quarterly, 33(4), 475-499

Herskovits, J. (1975). Nigeria: Africa's New Power. Foreign Affairs, 53 (2), 16-25.

International Trade Centre (2014) retrieved from www.intracen.org/itc/market-info-tools/tradestatistics on $25 / 3 / 2015$ 
Kushnir, I. (2013). World macroeconomic research, 1970-2013 retrieved online at http://kushnirs.org/macroeconomics/gdp/gdp_nigeria.html on 11/7/2015.

Mayall, J. (1976). Oil and Nigerian Foreign Policy. African Affairs, 75, 300-314.

Nwoke, C. (2005). Nigeria and ECOWAS in O. Joy (Ed.) new horizons for Nigeria in world affairs (111149). Lagos: NIIA Publications

Ogunsanwo, A. (2005). Nigeria and the European Union (EU): past, present and the future. ECOWAS in O. Joy (Ed.) new horizons for Nigeria in world affairs (pp.199-210). Lagos: NIIA Publications

Ogwu, J. (2005). Introduction: an overview. In O. Joy (Ed.) new horizons for Nigeria in world affairs (pp. 6-10). Lagos: NIIA Publications.

Oladimeji, T. \& Ahmad Zaki, A. (2015). Conceptualising multilateralism in the foreign policy of a regional power: a case study of Nigeria. International journal of research. 2(6), 401-409.

Oladimeji, T. \& Sherko, K. (2015). Nigeria's multilateral policy and regional order of West Africa in the post-cold war international system. International journal of physical and social sciences. 5(7), 682-698.

OPEC Annual statistical bulletin (2014) retrieved from http://www.opec.org/opec_web/static_files_project/media/downloads/publications/ASB2014. pdf On 11/2/2015

Osuntokun J. (2005). Historical Background Survey of Nigeria's foreign policy. In O. Joy (Ed.) new horizons for Nigeria in world affairs (pp. 29-50). Lagos: NIIA Publications.

Rodney, W. (1973). How Europe underdeveloped Africa. London: Bogle-L'Ouverture Publications.

Sanu, E. O. (1980). The Lome Convention and the New International Economic Order: A Public Lecture Delivered Under the Auspices of the Nigerian Institute of International Affairs, Victoria Island, Lagos (Vol. 18). The Nigerian institute of international affairs.

Shaw, T. M. (1983) Introduction: Nigeria as Africa's major power. In S.M Timothy \& A.Olajide (Eds), Nigerian foreign policy: alternative projections (pp 1-19). HongKong: Macmillan Press Ltd.

Shaw, T. M. (1984). The state of Nigeria: Oil crises, power bases and foreign policy. Canadian Journal of African Studies/La Revue canadienne des etudes Africaines, 18(2), 393-405.

Shaw, T. M., \& Fasehun, O. (1980). Nigeria in the World System: Alternative Approaches, Explanations, and Projections. The Journal of Modern African Studies, 18(04), 551-573.

Sun News (Ghana). (2014, September 16). Nigerians in Ghana control over 50\% real estate investments

Tetenyi, A. (2014). South Africa vs. Nigeria: competing countries for leadership position in Sub-Saharan Africa, paper presented at the ISA/FLACSO conference in Buenos Aires, Argentina on the 24th of July, 2014.

The Washington Post. (1977). "Nigeria Threatens Sanctions against Investors in South Africa", Washington D.C. 27 March.

Tyoden, S. (1983).Nigeria's development strategy in global perspective. In S.M Timothy \& A. Olajide (Eds), Nigerian foreign policy: alternative projections (pp.147163). Hong Kong: Macmillan Press Ltd.

United States Department of Agriculture (2014) retrieved from http:/ /www.indexmundi.com/agriculture/?commodity=palm-oil\&

World cocoa foundation (2014, April 1) Cocoa Market retrieved from http://worldcocoafoundation.org/wp-content/uploads/Cocoa-Market-Update-as-of-4-1-2014.pdf

Wright, S. (1983). Nigerian foreign policy: a case of dominance or dependency? In S.M Timothy \& A. Olajide (Eds), Nigerian foreign policy: alternative projections (pp.93-121). Hong Kong: Macmillan Press Ltd.

Wright, S. (1998). Africa and the global society: marginality, conditionality and conjuncture. In A. Sola \& S. Amadu (Eds), Africa in the post-cold war international system (pp. 134-146).Great Britain: Pinter Publishers. 